\title{
PENGARUH KOMITMEN PROFESI, KECERDASAN EMOSIONAL DAN PERENCANAAN KARIR TERHADAP KINERJA PEGAWAI DI DINAS PEKERJAAN UMUM DAN PENATAAN RUANG DAERAH KABUPATEN LABUHANBATU SELATAN
}

\author{
${ }^{1}$ Janra Mei Wandi Saragih, ${ }^{2}$ Husin, ${ }^{3}$ Martina Silaban, ${ }^{4}$ Lamsah Saragih, ${ }^{5}$ Widi Hastuti \\ $1,2,3,4,5$ Universitas Islam Sumatera Utara \\ 1 janra.wandi@gmail.com, ${ }^{2}$ husin.mm@gmail.com, ${ }^{3}$ martina.silaban@gmail.com, ${ }^{4}$ lamsah.saragih@gmail.com, \\ 5widi.hastuti@gmail.com
}

\begin{abstract}
The problems in research what is influence of profession commitment on performance. What is influence of emotional intellegence on performance. What is influence of career planning on performance. What is influence of profession commitment, emotional intellegence and career planning on performance. The research of purposes is for know and analysis influence of profession commitment on performance. For know and analysis influence of emotional intellegence on performance. For know and analysis influence of career planning on performance. For know and analysis influence of profession commitment, emotional intellegence and career planning on performance. Samples in the research amount to 52 employees people. Data analyze technique in the research using descriptive analyze and regression analize. The results of this research explain of profession commitment variable effect significant and positive on performance. Emotional intellegence variable effect significant and positive on performance. Career planning variable effect significant and positive on performance. Profession commitment, emotional intellegence and career planning variable effect significant and positive on performance.
\end{abstract}

Keywords : Profession commitment, Emotional intellegence, Career planning, Performance

ABSTRAK : Rumusan masalah dalam penelitian ini adalah apakah ada pengaruh komitmen profesi terhadap kinerja. Apakah ada pengaruh kecerdasan emosional terhadap kinerja. Apakah ada pengaruh perencanaan karir terhadap kinerja. Apakah ada pengaruh komitmen profesi, kecerdasan emosional dan perencanaan karir terhadap kinerja. Tujuan penelitian ini adalah untuk mengetahui dan menganalisis pengaruh komitmen profesi terhadap kinerja. Untuk mengetahui dan menganalisis pengaruh kecerdasan emosional terhadap kinerja. Untuk mengetahui dan menganalisis pengaruh perencanaan karir terhadap kinerja. Untuk mengetahui dan menganalisis pengaruh komitmen profesi, kecerdasan emosional dan perencanaan karir terhadap kinerja. Sampel dalam penelitian ini berjumlah 52 orang pegawai. Teknik analisis data dalam penelitian ini menggunakan analisis deskriptif dan analisis regresi linier berganda. Hasil penelitian ini menjelaskan bahwa variabel komitmen profesi berpengaruh positif dan signifikan terhadap kinerja. Variabel kecerdasan emosional berpengaruh positif dan signifikan terhadap kinerja,. Variabel perencanaan karir berpengaruh positif dan signifikan terhadap kinerja. Variabel komitmen profesi, kecerdasan emosional dan perencanaan karir berpengaruh positif dan signifikan terhadap kinerja

Kata kunci : Komitmen profesi, Perencanaan karir, Kecerdasan emosional, Kinerja

\section{Pendahuluan}

Sumber Daya Manusia merupakan determinan kemajuan suatu bangsa. Bangsa yang ingin memenangkan persaingan di era globalisasi ini harus mampu meningkatkan mutu Sumber Daya Manusianya. Begitu juga halnya di dalam suatu organisasi atau instansi, untuk meningkatkan kualitas Sumber Daya Manusia, maka banyak hal atau faktor yang harus diperhatikan seperti motivasi, komitmen, ketrampilan, kejujuran, kemauan untuk kerja keras, perhatian pimpinan, disiplin, tingkat kompetensi, karakteristik pekerjaan, perencanaan karir dan lain sebagainya, yang 
kesemuanya ini merupakan bagian dari sarana dan prasarana pendukung yang dibutuhkan untuk meningkatkan kualitas Sumber Daya Manusia.

Pentingnya kinerja pegawai dalam melaksanakan program kerja Kepegawaian Resor Padangsidimpuan semakin dirasakan. Menurut Rivai (2011:88) menjelaskan kinerja adalah perilaku nyata yang diperlihatkan oleh pegawai sebagai prestasi kerja yang dihasilkan sesuai dengan peranannya dalam organisasi. Menurut Siagian (2013:98), kinerja adalah hasil kerja secara kualitas dan kuantitas yang dicapai oleh seorang pegawai dalam melaksanakan tugasnya sesuai dengan tanggung jawab yang di berikan. Jadi kinerja dapat di pandang sebagai proses maupun hasil pekerjaan. Menurut Istijanto (2013:259), kinerja merupakan suatu proses tentang bagaimana pekerjaan berlangsung untuk mencapai hasil kerja. Oleh karena itu hasil kerja seorang pegawai, merupakan sebuah proses manajemen atau organisasi secara keseluruhan, dimana hasil kerja tersebut harus dapat di tunjukan buktinya secara konkrit dan dapat diukur (dibandingkan dengan standar yang telah ditentukan. Permasalahan kinerja pegawai Dinas Pekerjaan Umum dan Penataan Ruang Daerah Kabupaten Labuhanbatu Selatan terlihat bahwa hasil pekerjaan pegawai belum optimal. Jadi guna meningkatkan kinerja pegawai agar dapat optimal maka diperlukan suatu planning atau perencanaan dari pegawai.

Menurut Sutrisno (2011:13) menyatakan bahwa perencanaan karir adalah suatu yang mendasari karakteristik dari suatu individu yang dihubungkan dengan hasil yang diperoleh dalam suatu pekerjaan. Karakteristik dasar perencanaan karir adalah suatu yang kronis dan dalam bagian dari keperibadian seseorang dan dapat diramalkan perilaku di dalam suatu tugas pekerjaan. Menurut Robbins (2012:113) menyatakan terdapat empat hal yang mempengaruhi perencanaan karir, yaitu karakteristik keperibadian (seperti motivasi berprestasi, ketepatan (directness), dan fleksibilitas), sikap (seperti motivasi, empati terhadap pegawai, dan komitmen), pengalaman (seperti lama bekerja, pengalaman dalam suatu materi, dan pengalaman pada level instansi tertentu), dan bakat atau prestasi ( seperti skor pada tes perencanaan karir, indeks prestasi , dan hasil evaluasi). Karir seseorang pegawai tergantung pada banyak hal seperti tingkat pendidikan, lama bekerja, kepangkatan dan penilaian terhadap kinerja pegawai. Hasil penelitian terdahulu dari Dovian at.al (2017), dan Rimper at.al (2014), menyatakan bahwa perencanaan karir berpengaruh signifikan terhadap kinerja. Sedangkan fenomena yang terjadi di Dinas Pekerjaan Umum dan Penataan Ruang Daerah Kabupaten Labuhanbatu Selatan tentang perencanaan karir bahwa sistem kepangkatan, promosi dan mutasi ditentukan berdasarkan syarat administrasi yang jelas dan seleksi yang ketat sehingga menunjang profesionalisme pegawai. Karena adanya seleksi yang ketat dan syarat administrasi yang jelas menyebabkan banyak pegawai yang lambat dalam mengembangkan karirnya, hal ini ditambah lagi dengan adanya sistem birokrasi yang panjang prosesnya harus dipatuhi oleh para pegawai jika ingin mengusulkan kenaikan pangkat/jabatan.

Selain dari pada itu, guna mendukung kinerja pegawai Dinas Pekerjaan Umum dan Penataan Ruang Daerah Kabupaten Labuhanbatu Selatan diperlukan faktor komitmen profesi dari pegawai. Komitmen profesi paling sering didefenisikan sebagai keinginan kuat untuk tetap sebagai anggota profesi tertentu. Keinginan untuk berusaha keras sesuai keinginan profesi, keyakinan tertentu, dan penerimaan nilai dan tujuan profesi. Dengan kata lain, ini merupakan sikap yang merefleksikan loyalitas pegawai pada profesi dan proses berkelanjutan dimana anggota profesi mengekspresikan perhatiannya terhadap profesi dan keberhasilan serta kemajuan yang berkelanjutan, (Nitisemito, 2011:127). Menurut pendapat Krietner (2015:135), mendefenisikan komitmen profesi sebagai sebuah konsep yang memiliki tiga dimensi yaitu affective, normative, dan continuance commitment. Affective commitment adalah tingkat seberapa jauh seorang pegawai secara emosional terikat, mengenal, dan terlibat dalam organisasi. Continuance commitment adalah suatu penilaian terhadap biaya yang terkait dengan meninggalkan organisasi. Normative commitment merujuk kepada tingkat seberapa jauh seseorang secara phsychological terikat untuk menjadi pegawai dari sebuah organisasi yang didasarkan kepada perasaan seperti kesetiaan, afeksi, kehangatan, kepemilikan, kebanggaan, kesenangan, kebahagian, dan lain-lain. Penelitian terdahulu yang terkait pada komitmen profesi, yaitu penelitian yang dilakukan oleh Dhea (2016), Felisiana (2016) dan Fitriyani (2008) dengan 
hasil penelitian bahwa komitmen profesi berpengaruh signifikan terhadap kinerja. Fenomena yang terjadi di Dinas Pekerjaan Umum dan Penataan Ruang Daerah Kabupaten Labuhanbatu Selatan diantaranya masih terdapat kesenjangan atas pemahaman berbagai peraturan yang berhubungan dengan penyelenggaraan pekerjaan terutama di lapangan dan masih terdapat keterlambatan pelaporan atas hasil pekerjaan yang dilaksanakan

Untuk meningkatkan kinerja pegawai Dinas Pekerjaan Umum dan Penataan Ruang Daerah Kabupaten Labuhanbatu Selatan agar lebih baik perlu ditunjang adanya kecerdasan emosional dari dalam diri setiap pegawai. Menurut Goleman (2015:154), kecerdasan emosional adalah kemampuan untuk mengenali emosi diri, mengelola emosi, mengenali emosi orang lain, dan membina hubungan dengan orang lain. Beberapa penelitian terdahulu telah membuktikan bahwa variabel kecerdasan emosional memiliki pengaruh yang berarti terhadap motivasi dan kinerja pegawai diantaranya penelitian dari Fitriastuti (2013), dan Indra Gunawan (2014), Dengan demikian dapat disimpulkan bahwa seorang pegawai yang memiliki kecerdasan emosional yang tinggi (berkaitan dengan kemampuan mengenali emosi diri, mengelola emosi, mengenali emosi orang lain, dan membina hubungan dengan orang lain) maka pegawai tersebut cenderung memiliki motivasi dan kinerja yang tinggi dalam melaksanakan pekerjaannya. Untuk mengungkap fenomena tentang kecerdasan emosional pegawai Dinas Pekerjaan Umum dan Penataan Ruang Daerah Kabupaten Labuhanbatu Selatan, peneliti melakukan survei awal terhadap 10 orang pegawai Dinas Pekerjaan Umum dan Penataan Ruang Daerah Kabupaten Labuhanbatu Selatan, dengan hasil kebanyakan pegawai (8 orang) belum bisa bersikap sabar ketika menerima olok-olokan dari rekan kerja, sementara sebanyak 7 orang pegawai menyatakan bahwa mereka belum dapat memahami perasaan orang lain (rekan kerja), sehingga situasi ini dapat dikatakan bahwa kecerdasan emosional pegawai Dinas Pekerjaan Umum dan Penataan Ruang Daerah Kabupaten Labuhanbatu Selatan masih perlu mendapat perhatian.

\subsection{Batasan Masalah}

Mengingat ada beberapa permasalahan yang teridentifikasi dan dikarenakan waktu serta kemampuan yang penulis miliki dalam melaksanakan penelitian ini masih kurang, maka dari masalah-masalah yang teridentifikasi tersebut penulis mencoba membatasi masalah yang akan diteliti hanya pada masalah komitmen profesi, kecerdasan emosional, perencanaan karir dan kinerja.

\subsection{Hipotesis}

Hipotesis adalah jawaban sementara terhadap masalah penelitian, yang kebenarannya harus diuji secara empiris. Hipotesis dalam penelitian ini adalah :

1) Komitmen profesi berpengaruh positif dan signifikan terhadap kinerja pegawai di Dinas Pekerjaan Umum dan Penataan Ruang Daerah Kabupaten Labuhanbatu Selatan.

2) Kecerdasan emosional berpengaruh positif dan signifikan terhadap kinerja pegawai di Dinas Pekerjaan Umum dan Penataan Ruang Daerah Kabupaten Labuhanbatu Selatan.

3) Perencanaan karir berpengaruh positif dan signifikan terhadap kinerja pegawai di Dinas Pekerjaan Umum dan Penataan Ruang Daerah Kabupaten Labuhanbatu Selatan.

4) Komitmen profesi, kecerdasan emosional dan perencanaan karir berpengaruh positif dan signifikan terhadap kinerja pegawai di Dinas Pekerjaan Umum dan Penataan Ruang Daerah Kabupaten Labuhanbatu Selatan.

\subsection{Tujuan Penelitian}

Tujuan penelitian ini dilakukan adalah sebagai berikut :

1) Untuk mengetahui dan menganalisis pengaruh komitmen profesi terhadap kinerja pegawai di Dinas Pekerjaan Umum dan Penataan Ruang Daerah Kabupaten Labuhanbatu Selatan.

2) Untuk mengetahui dan menganalisis pengaruh kecerdasan emosional terhadap kinerja pegawai di Dinas Pekerjaan Umum dan Penataan Ruang Daerah Kabupaten Labuhanbatu Selatan.

3) Untuk mengetahui dan menganalisis pengaruh perencanaan karir terhadap kinerja pegawai di Dinas Pekerjaan Umum dan Penataan Ruang Daerah Kabupaten Labuhanbatu Selatan.

4) Untuk mengetahui dan menganalisis pengaruh komitmen profesi, kecerdasan emosional dan perencanaan karir terhadap kinerja pegawai di Dinas Pekerjaan Umum dan Penataan Ruang Daerah Kabupaten Labuhanbatu Selatan. 


\section{Metode Penelitian}

\subsection{Populasi}

Menurut Sugiyono (2009: 88), populasi adalah wilayah generalisasi yang terdiri atas obyek/subjek yang mempunyai kuantitas dan karakteristik tertentu yang ditetapkan oleh peneliti untuk dipelajari dan kemudian ditarik kesimpulannya. Jadi populasi bukan hanya orang tetapi juga benda-benda alam yang lain. Populasi juga bukan sekedar jumlah yang ada pada objek/subjek yang dipelajari, tetapi meliputi seluruh karakteristik, sifat yang dimiliki objek/subjek itu. Dari pengertian tersebut, maka dapat disimpulkan bahwa populasi merupakan subjek penelitian dimana individu yang akan dikenai perilaku atau dapat dikatakan sebagai keseluruhan objek penelitian yang akan diteliti. Maka yang menjadi populasi dalam penelitian ini adalah pegawai Dinas Pekerjaan Umum dan Penataan Ruang Daerah Kabupaten Labuhanbatu Selatan yang berjumlah 52 orang.

\subsection{Sampel}

Menurut Sugiyono (2009:93), sampel adalah elemen-elemen populasi yang dipilih atas dasar kemampuan mewakilinya. Untuk menjadi pedoman jika subjeknya atau populasinya kurang dari 100, maka lebih baik diambil semua sebagai sampel, sehingga penelitiannya merupakan penelitian populasi. Selanjutnya jika jumlah subjeknya atau populasinya besar atau lebih dari 100, maka dapat diambil persentasenya. Dengan teknik penarikan sampel secara total sampling, maka sampel dalam penelitian ini seluruh populasi yaitu 52 orang pegawai Dinas Pekerjaan Umum dan Penataan Ruang Daerah Kabupaten Labuhanbatu Selatan

Tabel 1. Kerangka sampel berdasarkan bagian

\begin{tabular}{|c|l|c|}
\hline No & \multicolumn{1}{|c|}{ Status } & Jumlah \\
\hline 1. & Sekretariat & 7 \\
\hline 2. & Bidang Cipta Karya & 10 \\
\hline 3. & Bidang Bina Marga & 9 \\
\hline 4. & $\begin{array}{l}\text { Bidang Sumber Daya Air } \\
\text { dan Drainase }\end{array}$ & 10 \\
\hline 5. & Bidang Penataan Ruang & 8 \\
\hline 6. & $\begin{array}{l}\text { Bidang Pertamanan dan } \\
\text { Penerangan }\end{array}$ & 8 \\
\hline \multicolumn{2}{|c|}{ Jumlah } & 52 \\
\hline
\end{tabular}

Sumber :Dinas Pekerjaan Umum dan Penataan Ruang Daerah Kabupaten Labuhanbatu Selatan, 2020

\subsection{Uji Normalitas}

Menurut Sugiyono (2014:144) pengertian dari uji normalitas adalah untuk menguji apakah nilai residual yang dihasilkan dari regresi terdistribusi secara normal atau tidak. Model regresi yang baik adalah yang memiliki nilai residual yang terdistribusi normal. Untuk mengetahui bentuk distribusi data, bisa dilakukan dengan grafik distribusi dan analisis statistik. Pengujian dengan distribusi dilakukan dengan melihat grafik histogram yang membandingkan antara dua observasi dengan distribusi yang mendekati distribusi normal. Distribusi normal akan membentuk satu garis lurus diagonal dan ploating data residual akan dibandingkan dengan garis diagonal. Jika distribusi atau residual normal, maka garis yang menggambarkan data yang sesungguhnya akan mengikuti garis diagonalnya. Uji normalitas dengan grafik dapat dilakukan dengan program SPSS dengan analisis grafik Normal Probability Plot

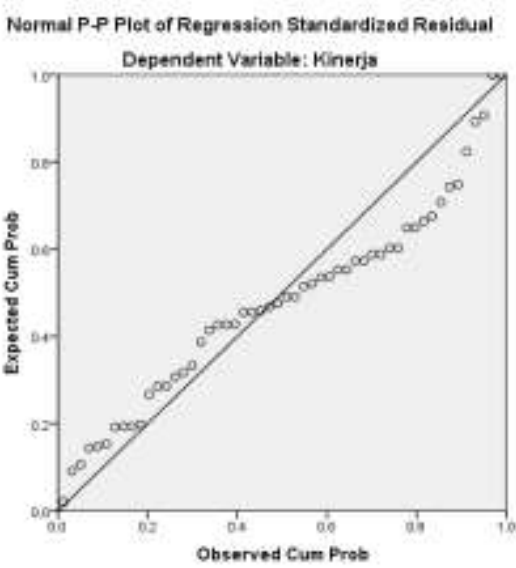

Gambar 1. Uji normalitas data

Hasil Pengolahan data penelitian, 2020

Berdasarkan gambar 1, diatas terlihat titiktitik dari ploating data residual berada di garis diagonal, hal ini dapat disimpulkan data yang diuji berdistribusi normal.

\subsection{Uji Multikolinieritas}

Salah satu asumsi dari model regresi linier bahwa tidak terjadi korelasi yang signifikan antara variabel bebasnya. Untuk menguji hal tersebut maka diperlukan suatu uji yang disebut uji multikolinieritas. Menurut Sugiyono (2014:151) pengertian multikolinieritas adalah keadaan di mana pada model regresi ditemukan adanya korelasi yang sempurna atau mendekati sempurna antar variabel independen. Pada regresi yang baik seharusnya tidak terjadi korelasi yang sempurna atau mendekati 
sempurna diantara variabel bebas. Uji multikolinieritas adalah untuk melihat ada atau tidaknya korelasi yang tinggi antara variabelvariabel bebasnya, maka hubungan antara variabel bebas terhadap variabel terikatnya menjadi terganggu. Jika terdapat korelasi yang kuat dimana sesama variabel independen maka konsekuensinya adalah :

a. Koefisien-koefisien regresi menjadi tidak dapat ditaksir

b. Nilai standar error setiap koefisien regresi menjadi tidak terhingga.

Dengan demikian, semakin besar korelasi diantara sesama variabel independen maka tingkat kesalahan dari koefisien regresi semakin besar yang dapat mengakibatkan standar error semakin besar pula. Cara yang digunakan untuk mendeteksi ada tidaknya multikolinieritas adalah dengan melihat besarnya nilai Variance Inflation Factor (VIF). Jika VIF dibawah 10 dan Tolerance Value diatas 0,1 maka tidak terjadi multikolinieritas.

Tabel 2. Uji multikolinieritas

\begin{tabular}{|l|c|c|}
\hline \multirow{2}{*}{\multicolumn{1}{|c|}{ Variabel }} & \multicolumn{2}{c|}{$\begin{array}{c}\text { Collinearity } \\
\text { Statistics }\end{array}$} \\
\cline { 2 - 3 } & Tolerance & VIF \\
\hline Komitmen profesi & 0.831 & 1.203 \\
\hline Kecerdasan emosional & 0.806 & 1.240 \\
\hline Perencanaan karir & 0.954 & 1.048 \\
\hline a Dependent Variable : Kinerja
\end{tabular}

Tabel 3. Uji Autokorelasi

\begin{tabular}{|c|c|c|c|c|c|c|}
\hline \multirow[b]{2}{*}{ Model } & \multicolumn{5}{|c|}{ Change Statistics } & \multirow{2}{*}{$\begin{array}{l}\text { Durbin- } \\
\text { Watson }\end{array}$} \\
\hline & $\begin{array}{c}\text { R Square } \\
\text { Change }\end{array}$ & F Change & df1 & df2 & $\begin{array}{l}\text { Sig. F } \\
\text { Change }\end{array}$ & \\
\hline 1 & .748 & 47.589 & 3 & 48 & .000 & 2.249 \\
\hline
\end{tabular}

Sumber : Hasil pengolahan data, 2020

Berdasarkan Tabel 3, di atas diperoleh nilai Durbin-Watson (DW) sebesar 2.249, nilai ini berada pada kisaran $1.65<\mathrm{DW}<2.35$, maka dapat disimpulkan bahwa tidak terjadi autokorelasi pada model regresi yang diuji dalam penelitian ini.

\subsection{Uji Heteroskedastisitas}

Uji heteroskedastisitas bertujuan untuk menguji apakah dalam model regresi terjadi ketidaksamaan variance dari residual satu pengamatan ke pengamatan yang lainnya. Gejala variance yang tidak sama ini disebut dengan heteroskedastisitas, sedangkan adanya gejala residual yang sama dari satu pengamatan ke pengamatan lain disebut dengan
Berdasarkan Tabel 2 diatas diperoleh nilai Tolerance Value diatas 0.1 yaitu 0.831, 0.806, 0.954; hal ini menunjukan adanya korelasi yang cukup tinggi/kuat antara sesama variabel bebas dan nilai Variance Inflantion Factorrs (VIF) sebesar 1.203, 1.240, 1.048, dimana nilai VIF dari ketiga varibel bebas lebih kecil dari 10 dan dapat disimpulkan tidak terdapat multikolinieritas diantara ketiga variabel bebas yang diuji dalam penelitian ini.

\subsection{Uji Autokorelasi}

Uji autokorelasi merupakan pengujian dimana variabel dependen tidak berkorelasi dengan nilai variabel itu sendiri, baik nilai periode sebelumnya maupun nilai periode sesudahnya. Menurut Sugiyono (2014:172) pengertian dari autokorelasi adalah keadaan di mana pada model regresi ada korelasi antara residual pada periode tertentu $t$ dengan residual pada periode sebelumnya ( $\mathrm{t}-1)$, model regresi yang baik adalah yang tidak terdapat masalah autokorelasi. Metode pengujian menggunakan uji Durbin-Watson (DW-test). Salah satu ukuran dalam menentukan ada tidaknya masalah autokorelasi dengan uji Durbin-Watson (DW) dengan ketentuan sebagai berikut :

$1.65<\mathrm{DW}<2.35$ tidak terjadi autokorelasi

1.21. $<\mathrm{DW}<1.65$ atau $2.35<\mathrm{DW}<2.79$ tidak dapat disimpulkan.

$\mathrm{DW}<1.21$ atau DW $>2.79$ terjadi autokorelasi. 
Dasar pengambilan keputusan yang dapat diambil adalah sebagai berikut :

a. Jika pola tertentu seperti titik-titik yang ada membentuk suatu pola yang teratur (bergelombang, melebar kemudian menyempit) maka telah terjadi heteroskedastisitas.

b. Jika tidak ada yang jelas serta titik-titik menyebar diatas dan dibawah angka nol pada sumbu $\mathrm{Y}$ maka tidak terjadi heteroskedastisitas

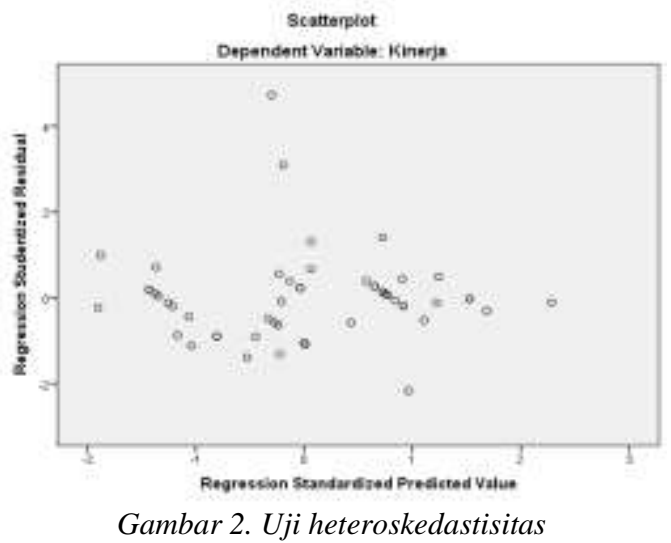

Tabel 4. Analisis regresi linier berganda

\begin{tabular}{|l|r|r|r|r|r|}
\hline \multirow{2}{*}{ Model } & \multicolumn{2}{|c|}{$\begin{array}{c}\text { Unstandardized } \\
\text { Coefficients }\end{array}$} & $\begin{array}{c}\text { Standardized } \\
\text { Coefficients } \\
\text { Beta }\end{array}$ & $\mathrm{t}$ & \multirow{2}{*}{ Sig. } \\
\cline { 2 - 3 } & \multicolumn{1}{|c|}{$\mathrm{B}$} & Std. Error & & \\
\hline (Constant) & -1.736 & 3.991 & & -.435 & .665 \\
\hline Komitmen profesi & .250 & .075 & .265 & 3.336 & .002 \\
\hline Kecerdasan emosional & .662 & .081 & .662 & 8.214 & .000 \\
\hline Perencanaan karir & .135 & .055 & .182 & 2.460 & .018 \\
\hline
\end{tabular}

Sumber : Hasil pengolahan data, 2020

Berdasarkan Tabel 4, diatas dapat dibuat persamaan regresi dalam penelitian ini sebagai berikut :

$Y=-1.736+0.250 X_{1}+0.662 X_{2}+0.135 X_{3}+e$

Dari persamaan regresi linier berganda di atas dapat dijelaskan :

1) Nilai kinerja pegawai di Dinas Pekerjaan Umum dan Penataan Ruang Daerah Kabupaten Labuhanbatu Selatan sebesar 1.736, dengan ketentuan nilai dari variabel bebas $\left(\mathrm{X}_{1}, \mathrm{X}_{2}\right.$, dan $\left.\mathrm{X}_{3}\right)$ diabaikan.

2) Nilai koefisien regresi $X_{1}$ (komitmen profesi) mempunyai nilai positif yaitu 0.250 , hal ini menunjukkan bahwa variabel komitmen profesi mempunyai pengaruh positif terhadap kinerja pegawai di Dinas Pekerjaan Umum dan Penataan Ruang Daerah Kabupaten Labuhanbatu Selatan.

3) Nilai koefisien regresi $X_{2}$ (kecerdasan emosional) mempunyai nilai positif yaitu 0.662 , hal ini menunjukkan bahwa variabel kecerdasan emosional mempunyai pengaruh
Berdasarkan gambar 2, diatas, menunjukkan titik-titik yang menyebar, sehingga dapat disimpulkan tidak terjadi heteroskedastisitas di data penelitian ini.

\section{Evaluasi dan Pembahasan}

\subsection{Hasil Analisis Regresi Linear Berganda}

Analisis regresi linier berganda dalam penelitian ini dapat dilihat dari persamaan regresinya, dan dari hasil pengolahan data diperoleh hasil berikut ini : positif terhadap kinerja pegawai di Dinas Pekerjaan Umum dan Penataan Ruang Daerah Kabupaten Labuhanbatu Selatan.

4) Nilai koefisien regresi $X_{3}$ (perencanaan karir) mempunyai nilai positif yaitu 0.135 , hal ini menunjukkan bahwa variabel perencanaan karir mempunyai pengaruh positif terhadap kinerja pegawai di Dinas Pekerjaan Umum dan Penataan Ruang Daerah Kabupaten Labuhanbatu Selatan.

\subsection{Pengaruh Komitmen Profesi Terhadap Kinerja Pegawai Di Dinas Pekerjaan Umum dan Penataan Ruang Daerah Kabupaten Labuhanbatu Selatan.}

Untuk mengetahui pengaruh komitmen profesi terhadap kinerja pegawai di Dinas Pekerjaan Umum dan Penataan Ruang Daerah Kabupaten Labuhanbatu Selatan. digunakan uji$\mathrm{t}$, sedangkan untuk melihat besarnya pengaruh digunakan nilai Beta atau Standardized Coefficient Beta. 
Tabel. 5. Pengaruh komitmen profesi terhadap kinerja

\begin{tabular}{|l|r|r|r|r|r|}
\hline \multirow{2}{*}{ Model } & \multicolumn{2}{|c|}{$\begin{array}{c}\text { Unstandardized } \\
\text { Coefficients }\end{array}$} & $\begin{array}{c}\text { Standardized } \\
\text { Coefficients } \\
\text { Beta }\end{array}$ & $\mathrm{t}$ & \multirow{2}{*}{ Sig. } \\
\cline { 2 - 3 } & \multicolumn{1}{|c|}{$\mathrm{B}$} & \multicolumn{1}{|c|}{ Std. Error } & & \\
\hline (Constant) & -1.736 & 3.991 & & -.435 & .665 \\
\hline Komitmen profesi & .250 & .075 & .265 & 3.336 & .002 \\
\hline
\end{tabular}

a. Dependent Variable : Kinerja

Dari Tabel 5, diatas diperoleh nilai $\mathrm{t}_{\text {hitung }}$ sebesar 3.336. Penelitian ini menggunakan taraf signifikansi $(\alpha: 0.05)$ dan Derajat Kebebasan (DK) dengan ketentuan DK $=\mathrm{n}-2$, atau $52-2$ $=50$. Dengan ketentuan tersebut, diperoleh nilai $\mathrm{t}_{\text {tabel }}$ sebesar 2.009. Dengan kriteria hipotesis sebagai berikut :

Jika nilai $t_{\text {hitung }}>t_{\text {tabel }}$, maka hipotesis penelitian diterima.

Jika nilai $t_{\text {hitung }}<\mathrm{t}_{\text {tabel}}$, maka hipotesis penelitian ditolak.

Dari hasil pengolahan data diperoleh nilai $t_{\text {hitung }}>t_{\text {tabel }}(3.336>2.009)$ dan nilai signifikasi lebih kecil dari nilai $\alpha: 0.05$ yaitu $0.002<0.05$, sehingga hipotesis yang diajukan dalam penelitian ini diterima. Artinya variabel komitmen profesi secara partial berpengaruh positif dan signifikan terhadap kinerja pegawai di Dinas Pekerjaan Umum dan Penataan Ruang Daerah Kabupaten Labuhanbatu Selatan. Besarnya pengaruh variabel komitmen profesi terhadap kinerja pegawai di Dinas Pekerjaan Umum dan Penataan Ruang Daerah Kabupaten Labuhanbatu Selatan sebesar 0.265 atau 26.50\%. Hasil penelitian ini sejalan dengan hasil penelitian Yuwalliatin (2006) yang mana menyatakan komitmen profesi berpengaruh positif dan signifikan terhadap kinerja. Deskripsi dari hasil penelitian ini adalah jika tingkat komitmen profesi sudah baik maka akan berdampak pada peningkatan kinerja pegawai, begitu juga sebalikny jika komitmen profesi pegawai belum baik, maka akan berdampak pada penurunan kinerja pegawai di Dinas Pekerjaan Umum dan Penataan Ruang Daerah Kabupaten Labuhanbatu Selatan.

\subsection{Pengaruh Kecerdasan Emosional Terhadap Kinerja Pegawai Di Dinas Pekerjaan Umum dan Penataan Ruang Daerah Kabupaten Labuhanbatu Selatan.}

Untuk mengetahui pengaruh kecerdasan emosional terhadap kinerja pegawai di Dinas Pekerjaan Umum dan Penataan Ruang Daerah Kabupaten Labuhanbatu Selatan digunakan uji$\mathrm{t}$, sedangkan untuk melihat besarnya pengaruh digunakan nilai Beta atau Standardized Coefficient Beta.

Tabel. 6. Pengaruh kecerdasan emosional terhadap kinerja

\begin{tabular}{|l|r|r|r|r|r|}
\hline \multirow{2}{*}{ Model } & \multicolumn{2}{|c|}{$\begin{array}{c}\text { Unstandardized } \\
\text { Coefficients }\end{array}$} & $\begin{array}{c}\text { Standardized } \\
\text { Coefficients } \\
\text { Beta }\end{array}$ & \multirow{2}{*}{$\mathrm{t}$} & \multirow{2}{*}{ Sig. } \\
\cline { 2 - 3 } & \multicolumn{1}{|c|}{$\mathrm{B}$} & Std. Error & & & \\
\hline (Constant) & -1.736 & 3.991 & & -.435 & .665 \\
\hline Kecerdasan emosional & .662 & .081 & .662 & 8.214 & .000 \\
\hline
\end{tabular}

a. Dependent Variable : Kinerja

Dari Tabel 6, diatas diperoleh nilai $\mathrm{t}_{\text {hitung }}$ sebesar 8.214. Penelitian ini menggunakan taraf signifikansi $(\alpha: 0.05)$ dan Derajat Kebebasan (DK) dengan ketentuan DK $=\mathrm{n}-2$, atau $52-2$ $=50$. Dengan ketentuan tersebut, diperoleh nilai $t_{\text {tabel }}$ sebesar 2.009. Dengan kriteria hipotesis sebagai berikut :

Jika nilai $t_{\text {hitung }}>t_{\text {tabel, }}$ maka hipotesis penelitian diterima.

Jika nilai $\mathrm{t}_{\text {hitung }}<\mathrm{t}_{\text {tabel}}$, maka hipotesis penelitian ditolak.

Dari hasil pengolahan data diperoleh nilai $t_{\text {hitung }}>t_{\text {tabel }}(8.214>2.009)$ dan nilai signifikasi lebih kecil dari nilai $\alpha: 0.05$ yaitu $0.00<0.05$, sehingga hipotesis yang diajukan dalam penelitian ini diterima. Artinya variabel kecerdasan emosional secara partial berpengaruh positif dan signifikan terhadap kinerja pegawai di Dinas Pekerjaan Umum dan Penataan Ruang Daerah Kabupaten Labuhanbatu Selatan. Besarnya pengaruh variabel kecerdasan emosional terhadap kinerja pegawai di Dinas Pekerjaan Umum dan Penataan Ruang Daerah Kabupaten Labuhanbatu Selatan sebesar 0.662 atau $66.20 \%$. Hasil penelitian ini sejalan dengan hasil penelitian Magnano, at.al (2016). Sontakke (2016), Shahab (2014), Babatunde, 
at.al (2014), Kumar, at.al (2013), Supriadi at.al (2017), Roy, at.al (2013), Yahaya, at.al (2012), yang mana kesemuanya menyatakan kecerdasan emosional berpengaruh positif dan signifikan terhadap kinerja. Deskripsi dari hasil penelitian ini adalah jika kecerdasan emosional pegawai sudah baik maka akan berdampak pada peningkatan kinerja pegawai, begitu juga sebaliknya jika kecerdasan emosional pegawai belum baik, maka akan berdampak pada penurunan kinerja pegawai di Dinas Pekerjaan Umum dan Penataan Ruang Daerah Kabupaten Labuhanbatu Selatan.

Tabel. 7. Pengaruh perencanaan karir terhadap kinerja

\begin{tabular}{|l|r|r|r|r|r|}
\hline \multirow{2}{*}{ Model } & \multicolumn{2}{|c|}{$\begin{array}{c}\text { Unstandardized } \\
\text { Coefficients }\end{array}$} & $\begin{array}{c}\text { Standardized } \\
\text { Coefficients } \\
\text { Beta }\end{array}$ & \multirow{2}{*}{$\mathrm{t}$} & \multirow{2}{*}{ Sig. } \\
\cline { 2 - 3 } & \multicolumn{1}{|c|}{$\mathrm{B}$} & \multicolumn{1}{|c|}{ Std. Error } & & \\
\hline (Constant $)$ & -1.736 & 3.991 & & -.435 & .665 \\
\hline Perencanaan karir & .135 & .055 & .182 & 2.460 & .018 \\
\hline
\end{tabular}

Dari Tabel 7, diatas diperoleh nilai $\mathrm{t}_{\text {hitung }}$ sebesar 2.460. Penelitian ini menggunakan taraf signifikansi $(\alpha: 0.05)$ dan Derajat Kebebasan (DK) dengan ketentuan DK $=\mathrm{n}-2$, atau $52-2$ $=50$. Dengan ketentuan tersebut, diperoleh nilai $\mathrm{t}_{\text {tabel }}$ sebesar 2.009. Dengan kriteria hipotesis sebagai berikut :

Jika nilai $t_{\text {hitung }}>t_{\text {tabel }}$, maka hipotesis penelitian diterima.

Jika nilai $\mathrm{t}_{\text {hitung }}<\mathrm{t}_{\text {tabel}}$, maka hipotesis penelitian ditolak.

Dari hasil pengolahan data diperoleh nilai $t_{\text {hitung }}>t_{\text {tabel }}(2.460>2.009)$ dan nilai signifikasi lebih kecil dari nilai $\alpha: 0.05$ yaitu $0.018<0.05$, sehingga hipotesis yang diajukan dalam penelitian ini diterima. Artinya variabel perencanaan karir secara partial berpengaruh positif dan signifikan terhadap kinerja pegawai di Madrasah Aliyah Negeri Kabupaten Batu Bara. Besarnya pengaruh variabel perencanaan karir terhadap kinerja pegawai di Dinas Pekerjaan Umum dan Penataan Ruang Daerah Kabupaten Labuhanbatu Selatan sebesar 0.182 atau $18.20 \%$. Hasil penelitian ini sejalan dengan hasil penelitian Dovian at.al (2017) dan Rimper at.al (2014), yang mana kesemuanya
3.4. Pengaruh Perencanaan Karir Terhadap Kinerja Pegawai Di Dinas Pekerjaan Umum dan Penataan Ruang Daerah Kabupaten Labuhanbatu Selatan.

Untuk mengetahui pengaruh perencanaan karir terhadap kinerja pegawai di Dinas Pekerjaan Umum dan Penataan Ruang Daerah Kabupaten Labuhanbatu Selatan digunakan uji$\mathrm{t}$, sedangkan untuk melihat besarnya pengaruh digunakan nilai Beta atau Standardized Coefficient Beta. menyatakan perencanaan karir berpengaruh positif dan signifikan terhadap kinerja. Deskripsi dari hasil penelitian ini adalah jika sistem atau program atau sistem perencanaan karir pegawai sudah berjalan dengan baik maka akan berdampak pada peningkatan kinerja pegawai, begitu juga sebaliknya jika sistem atau program atau sistem perencanaan karir pegawai belum berjalan dengan baik, maka akan berdampak pada penurunan kinerja pegawai di Dinas Pekerjaan Umum dan Penataan Ruang Daerah Kabupaten Labuhanbatu Selatan.

\subsection{Pengaruh Komitmen Profesi, Kecerdasan Emosional dan Perencanaan Karir Terhadap Kinerja Pegawai Di Dinas Pekerjaan Umum dan Penataan Ruang Daerah Kabupaten Labuhanbatu Selatan.}

Untuk mengetahui pengaruh komitmen profesi, kecerdasan emosional dan perencanaan karir terhadap kinerja pegawai di Dinas Pekerjaan Umum dan Penataan Ruang Daerah Kabupaten Labuhanbatu Selatan digunakan ujiF.

Tabel 8. Pengaruh komitmen profesi, kecerdasan emosional dan perencanaan karir terhadap kinerja

\begin{tabular}{|l|l|c|r|r|r|c|}
\hline Model & & $\begin{array}{c}\text { Sum of } \\
\text { Squares }\end{array}$ & \multicolumn{1}{c|}{$\mathrm{df}$} & $\begin{array}{c}\text { Mean } \\
\text { Square }\end{array}$ & \multicolumn{1}{c|}{$\mathrm{F}$} & \multicolumn{1}{c|}{ Sig. } \\
\hline \multirow{3}{*}{1} & Regression & 405.796 & 3 & 135.265 & 47.589 & $.000^{\mathrm{a}}$ \\
\cline { 2 - 7 } & Residual & 136.435 & 48 & 2.842 & & \\
\cline { 2 - 7 } & Total & 542.231 & 51 & & & \\
\hline
\end{tabular}

Dependent Variable : Kinerja 
Dari Tabel 8, di atas diperoleh nilai $\mathrm{F}_{\text {hitung }}$ sebesar 47.589. Penelitian ini menggunakan taraf signifikansi $(\alpha: 0.05)$ dan Derajat Kebebasan (DK) dengan ketentuan numerator : jumlah variabel -1 atau $4-1=3$, dan jumlah sampel dikurang 4 atau $52-4=48$. Dengan ketentuan tersebut, diperoleh nilai $\mathrm{F}_{\text {tabel }}$ sebesar 2.80. Dengan kriteria pengujian hipotesis sebagai berikut :

Jika $\mathrm{F}_{\text {hitung }}>\mathrm{F}_{\text {tabel}}$, maka hipotesis penelitian diterima.

Jika $F_{\text {hitung }}<\mathrm{F}_{\text {tabel }}$, maka hipotesis penelitian ditolak.

Dari hasil perhitungan diperoleh nilai $\mathrm{F}_{\text {hitung }}>\mathrm{F}_{\text {tabel }}(47.589>2.80)$ dan nilai signifikasi $0.00<0.05$, sehingga hipotesis yang diajukan dalam penelitian ini diterima. Artinya variabel komitmen profesi, kecerdasan emosional dan perencanaan karir secara simultan berpengaruh positif dan signifikan

Tabel 9. Model summary ${ }^{\mathrm{b}}$ pengaruh komitmen profesi, kecerdasan emosional dan perencanaan karir terhadap kinerja

\begin{tabular}{|l|r|r|r|r|}
\hline Model & $R$ & $R$ Square & $\begin{array}{c}\text { Adjusted } R \\
\text { Square }\end{array}$ & $\begin{array}{c}\text { Std. Error of the } \\
\text { Estimate }\end{array}$ \\
\hline 1 & $.865^{\mathrm{a}}$ & .748 & .733 & 1.68594 \\
\hline
\end{tabular}

Dependent Variable : Kinerja

Besarnya Tabel 9, diatas diperoleh nilai Adjusted Rsquare $\left(\mathrm{r}^{2}\right)$ sebesar 0.733. Nilai tersebut mempunyai maksud bahwa pengaruh variabel komitmen profesi, kecerdasan emosional dan perencanaan karir terhadap kinerja pegawai di Dinas Pekerjaan Umum dan Penataan Ruang Daerah Kabupaten Labuhanbatu Selatan sebesar $73.30 \%$, sedangkan sisanya sebesar $26.70 \%$ dipengaruhi oleh faktor-faktor lain yang tidak diteliti. Dengan kata lain variabel kinerja pegawai di Dinas Pekerjaan Umum dan Penataan Ruang Daerah Kabupaten Labuhanbatu Selatan dapat diterangkan oleh variabel komitmen profesi, kecerdasan emosional dan perencanaan karir sebesar $73.30 \%$, sedangkan sisanya sebesar $26.70 \%$ disebabkan oleh variabel-variabel lain yang tidak diteliti.

\section{Kesimpulan}

Berdasarkan pada pembahasan pada bab sebelumnya, maka dapat ditarik kesimpulan dari penelitian ini sebagai berikut :

1) Variabel komitmen profesi secara partial berpengaruh positif dan signifikan terhadap kinerja pegawai di Dinas Pekerjaan Umum dan Penataan Ruang Daerah Kabupaten Labuhanbatu Selatan. terhadap kinerja pegawai di Dinas Pekerjaan Umum dan Penataan Ruang Daerah Kabupaten Labuhanbatu Selatan. Dengan demikian model regresi ini sudah layak dan benar dan dapat disimpulkan bahwa variabel komitmen profesi, kecerdasan emosional dan perencanaan karir berpengaruh terhadap kinerja pegawai di Dinas Pekerjaan Umum dan Penataan Ruang Daerah Kabupaten Labuhanbatu Selatan.

\subsection{Uji Determinan}

Uji determinan adalah untuk mengetahui seberapa besar pengaruh variabel komitmen profesi, kecerdasan emosional dan perencanaan Pekerjaan Umum dan Penataan Ruang Daerah Kabupaten Labuhanbatu Selatan, dan dapat dilihat dari model summary, khususnya nilai Adjusted Rsquare. karir terhadap kinerja pegawai di Dinas
2) Variabel kecerdasan emosional secara partial berpengaruh positif dan signifikan terhadap kinerja pegawai di Dinas Pekerjaan Umum dan Penataan Ruang Daerah Kabupaten Labuhanbatu Selatan.

3) Variabel perencanaan karir secara partial berpengaruh positif dan signifikan terhadap kinerja pegawai di Dinas Pekerjaan Umum dan Penataan Ruang Daerah Kabupaten Labuhanbatu Selatan.

4) Variabel komitmen profesi, kecerdasan emosional dan perencanaan karir secara simultan berpengaruh positif dan signifikan terhadap kinerja pegawai di Dinas Pekerjaan Umum dan Penataan Ruang Daerah Kabupaten Labuhanbatu Selatan.

\section{DAFTAR PUSTAKA}

Amstrong Michael dan Helen Murlis (2013), Manajemen Imbalan, Buku Kedua, PT. Buana Ilmu Populer, Jakarta.

Bangun, W (2012), Manajemen Sumber Daya Manusia, Erlangga Jakarta

Barker, Alan (2009), Mengelola Sumber Daya Manusia, PT. Gramedia, Jakarta.

Buchori Zainun (2014), Manajemen dan Motivasi, Balai Aksara, Jakarta. 
Colquitt, J. A., LePine, J. A., and Wesson., (2009) Organizational Behavior: Improving Performance and Commitment in the Workplace, New York, McGraw Hill

Dessler, Garry (2017), Manajemen Sumber Daya Manusia, PT. Preshelindo, Jakarta.

Dovian Millian, Sudibjo Aji (2017), Pengaruh Perencanaan Karir Dan Motivasi Terhadap Kinerja Karyawan Pada PT. Cat Di Kota Malang,

http://journal.umg.ac.id/index.php/manajeri al/ article/view/186

Dhea Perdana Coenraad (2016), Pengaruh Kemampuan, Motivasi Dan Komitmen Terhadap Kinerja Pegawai, Jurnal Ekonomi, Bisnis \& Entrepreneurship Vol.10, No. 1, April 2016, 17-24

Felisiana Andini Permatasari, Ni Luh Gede Erni Sulindawati, SE. Ak,M, Dr. Edy

Sujana,SE,Msi,AK, (2016), Pengaruh Komitmen Profesi, Integritas, Objektivitas, Kompetensi, Dan Perilaku Profesional Terhadap Kinerja Auditor (Studi Empiris Pada Inspektorat Pemerintah Provinsi Bali, Kabupaten Bangli, dan Kabupaten

Klungkung), https://ejournal.undiksha.ac.id/index.php/S1ak /article/view/6654

Fitriastuti, T. (2013) 'Pengaruh Kecerdasan Emosional, Komitmen Organisasional Dan Organizational Citizenship Behavior Terhadap Kinerja Karyawan', Jurnal Dinamika Manajemen.

Fitriyani, Dwi Kartika (2008), Pengaruh Komitmen Profesional Terhadap Kinerja Auditor (Survey pada beberapa Kantor Akuntan Publik di Bandung), https://repository.widyatama.ac.id/xmlui/ handle/123456789/7089

Gorda, IGN. (2014), Manajemen Sumber Daya Manusia. Edisi Revisi. Cetakan Kedua. Denpasar: Astabrata

Handoko T, Hani (2009), Manajemen Personalia dan Sumber Daya Manusia, Edisi Kedua, BPFE Yogyakarta.

Hasibuan, Malayu, SP (2009), Manajemen Sumber Daya Manusia, PT. Bumi Akasara Jakarta.

Indra Gunawan, H. Sutadji, E. R. (2014), Pengaruh Kecerdasan Emosional Dan Komitmen Organisasi Terhadap Kinerja Pegawai Dinas Perkebunan Dan Kehutanan Kabupaten Kutai Kartanegara, eJournal
Administrative Reform, 2(2), p. 13. Available at: ar.mian.fisip-unmul.ac.id\%0D

Ishak Arep, dan Hendri Tanjung. 2004. Manajemen Motivasi. Grasindo, Jakarta.

Istijanto (2013), Riset Sumber Daya Manusia, Jakarta: PT. Gramedia Pustaka Utama

Krietner R dan Angelo Kinicki, (2015), Perilaku Organisasi, Salemba Empat Jakarta

Mangkunegara, Anwar, Prabu. (2009). Evaluasi Kinerja SDM, Cetakan 4, Bandung : Refika Aditama

Martoyo, Susili (2005), Manajemen Sumber Daya Manusia, Edisi Ketiga, Cetakan Keempat, Ghalia Jakarta

Mathis L. Robert dan Jackson H. John alih bahasa oleh Sadeli (2009), Manajemen Sumber Daya Manusia, Salemba Empat Jakarta.

Nitisemito S Alex (2009), Manajemen Personalia, Cetakan Keempat, Ghalia, Jakarta.

Ridwan (2007). Skala Pengukuran VariabelVariabel Alfabeta, Bandung

Rimper, R. R., \& Kawet, L. (2014), Pengaruh Perencanaan Karir dan Self Efficacy terhadap Kinerja Karyawan pada PT PLN (Persero) Area Manado. Jurnal EMBA, Vol.2 No.4 , 413- 423

Rivai, Veithzal dan Sagala, Ella Jauvani. (2011). Manajemen Sumber Daya Manusia Untuk Perusahaan : Dari Teori ke Praktek. Jakarta : PT. Rajagrafindo Persada

Robbins P. Stephen, Coulter Mary alih bahasa oleh Benyamin, (2012), Manajemen, Edisi keenam, Jilid 2, PT. Indeks Jakarta

Sanusi P. 2009. Memahami Aspek-Aspek Pengelolaan Sumber Daya Manusia Dalam Organisasi. Jakarta: Grasindo

Siagian, Sondang. (2013). Manajemen Sumber Daya Manusia (cetakan 15). Jakarta: Bumi Aksara

Simamora, H. (2014). Manajemen Sumber Daya Manusia. Edisi Ketiga. Yogyakarta: Sekolah Tinggi Ilmu Ekonomi YKPN

Sugiyono (2016) Metodologi Penelitian Kuantitatif, Kualitatif, dan R\&D, CV Alfabeta. doi: https://doi.org/10.3929/ethz-b000238666.

(2017) 'Metode Penelitian Bisnis (Pendekatan Kuantitatif, Kualitatif, Kombinasi dan R\&D)', in Metodelogi Penelitian. Bandung: Alfabeta, p. 334. Available at: www.alfabeta.com. 
(2014) 'Populasi dan sampel', Metode Penelitian Kuantitatif, Kualitatif dan $\mathrm{R} \& \mathrm{D}$

Sutrisno, Edy (2009), Manajemen Sumber Daya Manusia, Jakarta: Kencana

Thoha, Miftah (2010), Kepemimpinan Dalam Manajemen, Rajawali Jakarta

Triton PB (2015), Paradigma Baru Manajemen Sumber Daya Manusia, Tugu Yogyakarta (2010), SPSS 13.00 Terapan, Riset Statistik Parametrik, Andi, Yogyakarta

Wahjosumidjo (2015), Kepemimpinan dan Motivasi, Liberty Yogyakarta

Wibowo, (2010). Manajemen Kinerja. Cetakan Pertama. Jakarta: Raja Grafindo Persada. 